\title{
Pengaruh Rasio Keuangan, Kepemilikan Saham, dan Indikator Makroekonomi Terhadap Financial Distress
}

\author{
Rahmawati Setiyoharini \\ Universitas Singaperbangsa Karawang \\ 1710631020179@student.unsika.ac.id \\ Endang Taufiqurahman \\ Universitas Singaperbangsa Karawang \\ Endangtaufiq@yahoo.co.id
}

\begin{abstract}
Abstrak Kebangkrutan merupakan hal yang tidak diinginkan oleh pengusaha manapun dan umumnya terjadi ketika perusahaan menghadapi kesulitan keuangan (financial distress). Penelitian ini dilakukan guna mengetahui, menganalisis serta menjelaskan faktor internal maupun eksternal yang mengakibatkan financial distress pada sektor transportasi. Penelitian ini menggunakan rasio keuangan (CR, DER, TATO, dan ROA), kepemilikan saham (manajerial dan institusional), dan indikator makroekonomi (inflasi dan kurs) untuk memprediksi financial distress. Altman Z-Score dimanfaatkan sebagai parameter financial distress. Metode pada penelitian ini ialah deskriptif verifikatif dengan pendekatan kuantitatif. Periode penelitian selama 2015-2019 dengan penentuan sampel menggunakan pusposive sampling. Pengolahan data memanfaatkan aplikasi SPSS 25 dengan analisis regresi berganda. Penelitian ini menghasilkan DER, TATO, kepemilikan manajerial, dan kepemilikan institusional berpengaruh signifikan terhadap financial distress. Sedangkan faktor CR, ROA, inflasi, dan kurs tidak signifikan mempengaruhi financial distress. Serta secara simultan segala faktor tersebut signifikan mempengaruhi financial distress, dibuktikan sebesar 61,2\% faktor dalam penelitian mempengaruhi financial distress.
\end{abstract}

Kata Kunci rasio keuangan, kepemilikan saham, indikator makroekonomi, financial distress.

\section{PENDAHULUAN}

Kian lama seiring berjalannya waktu, jumlah perusahaan yang mendaftarkan dirinya atau melakukan listing pada Bursa Efek Indonesia semakin bertambah tiap tahunnya. Secara tidak langsung hal ini mengartikan bahwa kondisi perekonomian Indonesia semakin berkembang. Namun dengan adanya hal tersebut perusahaan semakin dituntut untuk dapat mengelola bisnisnya dan beradaptasi dengan baik agar tetap dapat bertahan menghadapi persaingan bisnis. Sehingga perusahaan juga harus lebih berhati-hati terhadap kemungkinan kebangkrutan.

Kebangkrutan merupakan hal yang sangat dihindari dan tentunya tidak diharapkan oleh pelaku usaha manapun. Namun kemungkinan tersebut tetaplah ada dan mungkin dapat terjadi. Terlebih lagi jika perusahaan tidak dalam keadaan yang baik atau kurang sehat. 
Kemungkinan kebangkrutan dapat dimulai dikala perusahaan berada pada posisi menghadapi kesulitan keuangan (Financial Distress). Kondisi yang terus berlanjut sangat berbahaya bagi kelangsungan perusahaan itu sendiri.

Kondisi financial distress dapat dilihat dengan memanfaatkan metode perhitungan yang mampu memprediksi kemungkinan serta tingkat kesulitan yang dialami perusahaan. Metode tersebut adalah Altman Z-Score yang mampu menunjukkan 3 kategori pada perusahaan, yaitu kategori sehat (non-distress), tidak sehat (distress), dan grey area. Selama tahun 2015-2019 diketahui sebagian besar perusahaan dalam sektor transportasi mengalami financial distress, dilihat dari nilai Z-Score yang rendah tersebut. Dengan kondisi keuangan yang kurang baik tersebut mampu mempengaruhi minat investor dalam berinvestasi.

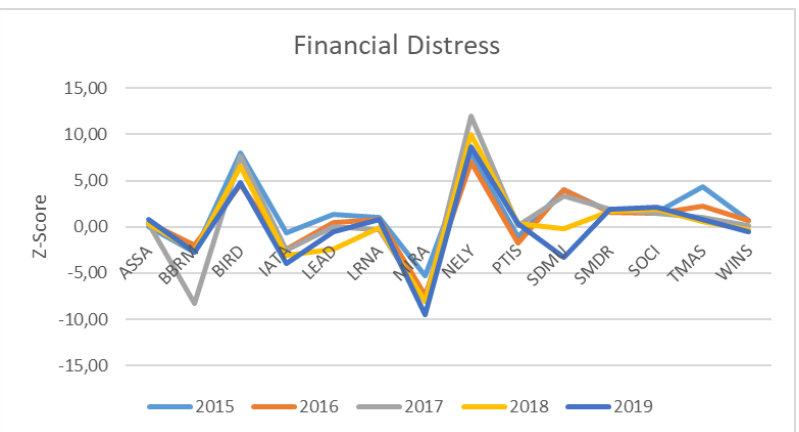

Gambar 1.1 Financial Distress Sektor Transportasi 2015-2019

Sumber Gambar : data diolah peneliti, 2021

Kondisi financial distress yang berlangsung pada suatu perusahaan bisa disebabkan dari beragam faktor internal maupun eksternal. Salah satu faktor luar perusahaan yang turut berpengaruh yaitu makroekonomi, dimana inflasi dan pergerakan kurs yang terjadi. Pergerakan kurs yang terjadi sejak 2015-2019 cukup berfluktuatif, dan hal ini mampu mempengaruhi kegiatan operasional perusahaan yang menggunakan bahan baku atau sumber tanaga dari luar negeri. Selain itu, perubahan harga yang terjadi terus menerus juga mengakibatkan meningkatknya harga barang lain, sehingga mempengaruhi terjadinya inflasi.

Selain faktor eskternal, tentunya faktor internal juga memiliki peranan penting atas kondisi keuangan perusahaan. Kondisi financial distress diketahui bermula saat perusahan tidak mampu memenuhi kewajiban berjangkanya. Sebagaimana hal yang pernah terjadi, beberapa perusahaan bahkan mengalami kebangkrutan dikarenakan ketidakmampuan perusahaan dalam mengelola keuangannya dengan baik. PT Citra Maharlika Nusantara Corpora Tbk atau yang kita ketahui sebagai Cipaganti, dan PT Arpeni Pratama Ocean Line Tbk, pernah dinyatakan pailit dan delisting dari BEI. Hal tersebut memiliki hubungan dengan kinerja perusahaan dalam mengelola seluruh keuangan perusahaan yang dapat kita ketahui dengan memperhatikan rasio keuangan perusahaan.

Rasio likuiditas dan solvabilitas turut berperan dalam mengenali kapabilitas perusahaan menyanggupi kewajiban berjangkanya, baik dalam rentang waktu dekat maupun jauh. Rasio likuiditas diukur dengan current ratio dan debt to equity ratio selaku penentu rasio solvabilitas. Tak hanya itu rasio aktivitas juga rasio profitabilitas diperlukan guna menilai kondisi keuangan perusahaan. Rasio aktivitas memanfaatkan total asset turnover sebagai penentu dalam melihat kemampuan perusahaan mengelola kegiatan operasional perusahaan. Dan rasio profitabilitas dengan return on assets (ROA) berguna melihat kapabilitas perusahaan memperoleh laba. 
Faktor internal lainnya yang mampu mempengaruhi kondisi financial distress adalah adanya perbedaan perilaku ataupun kesalahan yang dilakukan oleh pihak perusahaan yang dapat menimbulkan kerugian pada perusahaan (Hartianah \& Sulasmiyati, 2017). Kejadian yang terjadi tersebut sering dikenal dengan istiliah agency problem. Dan hal tersebut dapat diatasi dengan adanya bagian kepemilikan saham manajerial serta institusional. Dikarenakan kedua belah pihak sama-sama berperan sebagai pemegang saham yang tentunya menginginkan pengembalian yang baik dari saham yang ditanamnya.

Pada nyatanya tidak ada tidak ada satupun pihak yang menginginkan sebuah perusahaan mengalami kesulitan keuangan bahkan sampai mengalami kebangkrutan. Maka dari itu perlu untuk memahami berbagai faktor yang mampu mempengaruhi financial distress agar dapat dihindari sedini mungkin.

\section{LANDASAN TEORI}

A. 1. Financial Distress

Financial distress yaitu sebuah kondisi dimana terjadinya penurunan keuangan perusahaan terus meneruh bahkan mungkin lebih parah setiap tahunnya, dan kondisi ini terjadi saat sebelum perusahaan mengalami kebangkrutan ataupun likuidasi (Platt \& Platt, 2002). Kondisi ini dapat terjadi apabila kewajiban lancar tidak dapat dipenuhi dengan arus kas, sehingga perusahaan harus menarik sebuah keputusan sebagai aksi perbaikan (Sudana, 2019). Cara yang digunakan pada penelitian ini untuk menentukan financial distress adalah memanfaatkan Altman Z-Score. Dimana cara ini memiliki tingkat akurasi hingga $72 \%$ dalam memprediksi suatu kebangkrutan dengan waktu 2 tahun dan tingkat akurasi $80-90 \%$ dalam memprediksi kebangkrutan dalam waktu satu tahun (Altman dalam Matturungan et al., 2017). Rumus Altman Z-Score yang tepat digunakan dalam penelitian ini yaitu:

Keterangan:

$$
Z=6,56 X_{1}+3,26 X_{2}+6,72 X_{3}+1,05 X_{4}
$$

$\mathrm{Z}=$ Overall index (Z-Score)

$\mathrm{X} 1=$ Working Capital to Total Assets

$\mathrm{X} 2=$ Retained Earning to Total Assets

$\mathrm{X} 3=$ EBIT to Tax to Total Assets

X4 = Market Value Equity to Total Liabilities

Berdasarkan poin Z-Score yang didapatkan, perusahaan dapat diklasifikasikan sebagai berikut (Hery, 2017):

a. Jika nilai $\mathrm{Z}<1,1$ perusahaan terkategori financial distress.

b. Jika nilai $1,1<\mathrm{Z}<2,6$ perusahaan terkategori grey area (tidak ditetapkan sehat/tidak).

c. Jika nilai $Z>2,6$ perusahaan terkategori sehat, (non-distress).

\section{Rasio Keuangan}

Rasio keuangan yaitu suatu aktivitas yang dilakukan demi memperoleh informasi keuangan dengan membandingkan antar bagian komponen yang termuat dalam laporan keuangan (Kasmir, 2017).

Rasio Likuiditas merupakan rasio-rasio yang dimanfaatkan sebagai alat ukur guna menilai kesanggupan perusahaan dalam membayar utang jangka pendek yang dimiliki. Likuiditas menyatakan kesanggupan perusahaan memenuhi utang lancarnya dengan memanfaatkan aset lancarnya. Perusahaan dengan kinerja baik serta dalam kondisi likuid 
dapat meminimalisir perusahan dari financial distress (Kurniasanti \& Musdholifah, 2018).

$$
\text { Current Ratio }(C R)=\frac{\text { Current Assets }}{\text { Current Liabilities }}
$$

Rasio Solvabilitas berguna untuk menilai berapa banyak aktiva yang dimiliki oleh perusahaan dari hasil pembiayaan utang. Debt to equity ratio (DER) dimanfaatkan guna mengukur solvabilitas perusahaan, dimana rasio ini berfungsi memperkirakan berapa banyak jaminan utang yang berasal dari modal (Kasmir, 2017).

$$
\text { Debt to Equity Ratio }(D E R)=\frac{\text { Total Liabilities }}{\text { Total Equity }}
$$

Rasio Aktivitas yaitu rasio yang dimanfaatkan sebagai alat untuk menakar seberapa mampu perusahaan dalam mengelola aktiva perusahaan dengan cara efektif dan efisien (Kasmir, 2017). Total Assets Turnover (TATO) dipakai untuk menakar seberapa cepat pergerakan aset perusahaan dalam menghasilkan pendapatan. Pengelolaan aset dikatakan efektif apabila rasio ini memiliki nilai yang tinggi (Adinda \& Musdholifah, 2020).

$$
\text { Total Assets Turnover }(\text { TATO })=\frac{\text { Sales }}{\text { Total Assets }}
$$

Rasio Profitabilitas yaitu rasio yang dimanfaatkan guna menilai tingkat kapabilitas perusahaan dalam mencetak profit dengan memakai sumber daya yang dimiliki (Kasmir, 2017). Rasio profitabilitas diukur menggunakan Return on Assets (ROA) guna menilai kapabilitas perusahaan dalam mendapatkan laba (profit). Semakin baik presentase ROA menggambarkan efisiensi manajemen aset yang dikakukan perusahaan. (Sudana, 2019).

$$
\text { Return on Assets }(R O A)=\frac{\text { Net Profit }}{\text { Total Assets }}
$$

\section{Kepemilikan Saham}

Struktur kepemilikan merupakan bagian atas suatu kepemilikan saham perusahaan yang dibagi atas kepemilikan oleh pemilik perusahaan dan oleh pihak manajemen. Terdapat tiga jenis dalam struktur kepemilikan, yaitu kepemilikian institusional, kepemilikan manajerial, dan kepemilikan minoritas atau publik (Jensen \& Meckling, 1976). Semakin banyak keterlibatan pemilik dan semakin terpusatnya suatu kepemilikan, berefek pada kemampuan pemegang saham dalam memengaruhi keputusan yang akan dibuat oleh perusahaan (Mintzberg, 1983).

Kepemilikan Manajerial merupakan bagian saham perusahaan yang dipunyai oleh pihak manajemen, semacam komisaris, direksi, sekretaris, serta karyawan (Adinda \& Musdholifah, 2020). Dalam hal ini manajer (direktur) juga berperan dalam kepemilikan saham akan berupaya untuk bekerja secara optimal demi meningkatkan nilai perusahaan, dan akan meningkatkan kekayaan atas pengembalian dari hasil kepemilikan saham tersebut. Dengan kata lain dapat dikatakan kesejahteraan pemegang saham akan meningkat pula (Idarti \& Hasanah, 2018).

$$
\text { Kepemilikan Manajerial }=\frac{\text { Saham manajerial }}{\text { Total Saham Beredar }}
$$

Kepemilikan institusional yaitu bagian saham perusahaan yang dipunyai oleh pihak institusi atau perusahaan lain dalam maupun luar negeri (Adinda \& Musdholifah, 2020). Institusi atau lembaga dalam kepemilikan institusional ini biasanya berbentuk perusahaan asuransi, investasi, bank dan perusahaan lainnya. Kepemilikan institusional ini dibentuk dengan harapan jika suatu saat perusahaan mengalami kondisi kesulitan keuangan, pihak- 
pihak lembaga institusi yang turut menanamkan modalnya bersedia untuk memberi bantuan untuk perusahaan (Jenny \& Wijayanti, 2018).

$$
\text { Kepemilikan Institusional }=\frac{\text { Saham Institusional }}{\text { Total Saham Beredar }}
$$

\section{Makroekonomi}

Makroekonomi adalah studi perihal ekonomi secara menyeluruh, yang didalamnya meliputi inflasi, pengangguran dan perkembangan ekonomi (Mankiw, 2018). Keadaan makroekonomi yang terjadi merupakan di luar kendali perusahaan, sehingga hal ini mampu saja membuat perusahaan mengalami financial distress.

Inflasi dapat diartikan sebagai meningginya harga barang yang mampu mempengaruhi barang lainnya secara umum dan berkelanjutan dalam jangka waktu tertentu (BI, 2021). Indikator yang biasa dipakai dalam mengukur tingkat inflasi pada suatu negara yaitu Indeks Harga Konsumen (IHK). IHK sendiri merupakan suatu indeks yang menjelaskan jumlah konsumsi masyarakat atas barang serta jasa secara rata-rata, dan perubahan IHK yang terjadi setiap waktunya menunjukkan daya konsumsi masyarakat terhadap barang dan jasa tersebut (Hartianah \& Sulasmiyati, 2017).

$$
I H K=\frac{I H K_{t}-I H K_{t-1}}{I H K_{t-1}} \times 100 \%
$$

Nilai Tukar (Kurs) harga untuk menyatakan seberapa banyak suatu mata uang yang mesti ditukarkan demi memperoleh satu unit mata uang asing (Rahardja \& Manurung, 2017). Nilai kurs tengah yang dipublikasi oleh Bank Indonesia dimanfaatkan sebagai penentu variabel ini.

$$
\text { Kurs Tengah }=\frac{\text { Kurs Jual }+ \text { Kurs Beli }}{2}
$$

\section{METODOLOGI PENELITIAN}

Penelitian ini memanfaatkan metode deskriptif verifikatif untuk mendeskripsikan dan mengenali pengaruh yang terjadi antara variabel dependen berupa financial distress dengan variabel independen berupa CR, DER, TATO, ROA, Kepemilikan Manajerial dan Institusional, serta Inflasi dan Kurs. Penelitian ini memanfaatkan data kuantitatif dengan sumber data sekunder yang didapatkan dari laporan keuangan perusahaan sektor transportasi yang terdaftar di BEI serta data keuangan yang dipublikasikan BI. Populasi dalam penelitian ini adalah semua perusahaan sektor transportasi yang terdaftar di BEI tahun 2015-2019, yaitu sebanyak 45 perusahaan. Penentuan sampel menggunakan purposive samping didapatkan sebanyak 14 perusahaan. Persamaan regresi linier berganda pada penelitian ini adalah sebagai berikut:

$$
Y=\alpha+b_{1} X_{1}+b_{2} X_{2}+b_{3} X_{3}+b_{4} X_{4}+b_{5} X_{5}+b_{6} X_{6}+b_{7} X_{7}+b_{8} X_{8}+e
$$

\section{Keterangan:}

$$
\begin{array}{ll}
\mathrm{Y} & =\text { Financial Distress } \\
\alpha & =\text { Konstanta } \\
\mathrm{b}_{1}-\mathrm{b}_{8} & =\text { Koefisien regresi } \\
\mathrm{X} 1 & =\text { Current Ratio (CR) } \\
\mathrm{X} 2 & =\text { Debt to Equity Ratio (DER) } \\
\mathrm{X} 3 & =\text { Total Assets Turnover (TATO) } \\
\mathrm{X} 4 & =\text { Return on Assets (ROA) } \\
\mathrm{X} 5 & =\text { Kepemilikan Manajerial } \\
\mathrm{X} 6 & =\text { Kepemilikan Institusional }
\end{array}
$$


$\mathrm{X} 7 \quad=$ Inflasi

$\mathrm{X} 8=$ Nilai Tukar (Kurs)

\section{HASIL PENELITIAN}

\section{Analisis Deskriptif}

Dari Tabel 4.1 berikut diketahui jumlah data sampel sebanyak 70 dengan nilai rata-rata setiap variabel selama 2015-2019 yaitu CR sebesar 132,619\%, DER sebesar 107,763\%, TATO sebesar 39,527\%, ROA sebesar $-3,171 \%$, Kepemilikan Manajerial sebesar 11,426\%, Kepemilikan Institusional sebesar 58,185\%, Inflasi sebesar 3,990\%, kurs sebesar Rp 13.695, dan nilai financial distress sebesar 0,620.

Tabel 4.1. Analisis Deskriptif

\begin{tabular}{|l|r|r|r|r|r|}
\hline \multicolumn{7}{|c|}{ Descriptive Statistics } \\
\hline & N & \multicolumn{1}{|c|}{$\begin{array}{c}\text { Minim } \\
\text { um }\end{array}$} & $\begin{array}{c}\text { Maxim } \\
\text { um }\end{array}$ & Mean & $\begin{array}{c}\text { Std. } \\
\text { Deviatio } \\
\mathrm{n}\end{array}$ \\
\hline CR & 70 & 8.26 & 603.82 & 132.619 & 134.158 \\
\hline DER & 70 & 8.10 & 325.39 & 107.763 & 78.794 \\
\hline TATO & 70 & 11.45 & 96.57 & 39.527 & 21.297 \\
\hline ROA & 70 & -40.11 & 17.80 & -3.171 & 9.609 \\
\hline KepMan & 70 & .00 & 66.40 & 11.426 & 18.367 \\
\hline KepIns & 70 & 18.38 & 97.13 & 58.185 & 24.224 \\
\hline Inf & 70 & 3.03 & 6.38 & 3.990 & 1.233 \\
\hline Kurs & 70 & 13307 & 14250 & 13695 & 414.532 \\
\hline FD & 70 & -9.48 & 11.93 & .620 & 4.129 \\
\hline $\begin{array}{l}\text { Valid } \\
\text { N(listwi } \\
\text { se) }\end{array}$ & 70 & & & & \\
\hline
\end{tabular}

Sumber: Data diolah dengan SPSS 25, 2021

\section{Uji Asumsi Klasik}

\section{Uji Normalitas}

Penentuan normalitas dilihat dari hasil uji pada nilai signifikansi yang dihasilkan, apabila nilai signifikansi (Asymp. Sig.) > 0.05 data dikatakan terdistribusi normal, begitupun sebaliknya. Dilihat pada Tabel 4.2, didapatkan hasil nilai signifikansi 0,200 >0,50, mengartikan data dalam penelitian terdistribusi normal.

Tabel 4.2. Uji Normalitas

\begin{tabular}{|c|l|r|}
\hline \multicolumn{2}{|c|}{ One-Sample Kolmogorov-Smirnov Test } \\
\hline \multicolumn{2}{|c|}{} & $\begin{array}{c}\text { Unstandardized } \\
\text { Residual }\end{array}$ \\
\hline N & 70 \\
\hline \multirow{2}{*|}{ Normal Parameters ${ }^{\mathrm{a}, \mathrm{b}}$} & Mean & .0000000 \\
\cline { 2 - 3 } & Std. Dev & .24743273 \\
\hline
\end{tabular}


Jurnal Ekonomi \& Ekonomi Syariah Vol 5 No 1, Januari 2022

E-ISSN : 2599-3410 | P-ISSN : 2614-3259

DOI : https://doi.org/10.36778/jesya.v5i1.494

\begin{tabular}{|l|l|r|}
\hline Most Extreme Differences & Absolute & .084 \\
\cline { 2 - 3 } & Positive & .070 \\
\cline { 2 - 3 } & Negative & -.084 \\
\hline Test Statistic & .084 \\
\hline Asymp. Sig. (2-tailed) & $.200^{\mathrm{c}, \mathrm{d}}$ \\
\hline
\end{tabular}

Sumber: data diolah dengan SPSS 25, 2021

\section{Uji Multikolinearitas}

Penentuan data terbebas dari multikolinearitas apabila nilai tolerance $>0,10$ dan VIF $<10,00$. Pada Tabel 4.3 didapatkan hasil yaitu terbebas dari multikolinieritas karena seluruh variabel memenuhi ketentuan yang digunakan.

Tabel 4.3. Uji Multikoliniearitas

\begin{tabular}{|c|l|r|r|}
\hline \multicolumn{3}{|c|}{ Coefficients $^{\text {a }}$} \\
\hline \multirow{2}{*}{ Model } & \begin{tabular}{l} 
Collinearity \\
Statistics \\
\cline { 2 - 3 }
\end{tabular} & Tolerance & \multicolumn{1}{c|}{ VIF } \\
\hline \multirow{2}{*}{1} & (Constant) & & \\
\cline { 2 - 4 } & CR & .456 & 2.192 \\
\cline { 2 - 4 } & DER & .436 & 2.293 \\
\hline & TATO & .576 & 1.735 \\
\cline { 2 - 4 } & ROA & .429 & 2.329 \\
\cline { 2 - 4 } & KepMan & .615 & 1.627 \\
\cline { 2 - 4 } & KepIns & .873 & 1.146 \\
\cline { 2 - 4 } & Inf & .619 & 1.616 \\
\cline { 2 - 4 } & Kurs & .614 & 1.629 \\
\hline
\end{tabular}

Sumber: Data diolah dengan SPSS 25, 2021

\section{Uji Heterokedastisitas}

Uji glesjer dimanfaatkan guna menguji heterokedastisitas dalam peneltian ini Data yang baik merupakan yang terbebas dari heterokedastisitas dengan syarat nilai sig. $>0,05$. Dari Tabel 4.4, setiap variabel memiliki nilai sig. > 0,05, maka variabel yang digunakan terbebas dari heterokedastisitas.

Tabel 4.4. Uji Heterokedastisitas

\begin{tabular}{|c|c|c|c|c|c|c|}
\hline & & & oefficier & & & \\
\hline & & $\begin{array}{r}\text { Unstan } \\
\text { Coeff }\end{array}$ & $\begin{array}{l}\text { dized } \\
\text { nts. }\end{array}$ & $\begin{array}{l}\text { Standardized } \\
\text { Coefficients }\end{array}$ & $\mathrm{t}$ & Sig. \\
\hline & & B & $\begin{array}{l}\text { Std. } \\
\text { Error }\end{array}$ & Beta & & \\
\hline 1 & (Constant) & 6.232 & 8.889 & & .701 & .486 \\
\hline & CR & .067 & .035 & .326 & 1.903 & .062 \\
\hline & DER & -.032 & .036 & -.158 & -.904 & .369 \\
\hline & TATO & -.017 & .050 & -.052 & -.340 & .735 \\
\hline & ROA & .068 & .625 & .019 & .108 & .914 \\
\hline & KepMan & .002 & .006 & .047 & .319 & .751 \\
\hline & KepIns & -.024 & .046 & -.064 & -.513 & .609 \\
\hline & Inf & -.014 & .097 & -.022 & -.148 & .883 \\
\hline
\end{tabular}




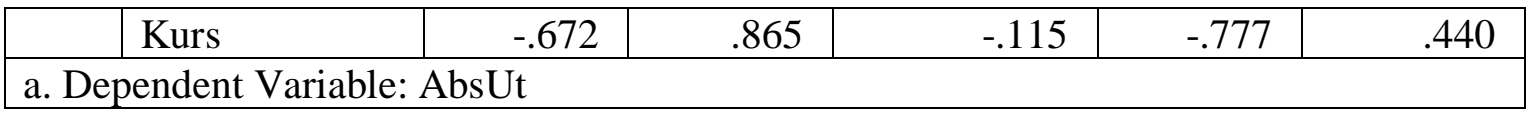

Sumber: Data diolah dengan SPSS 25, 2021

\section{Uji Autokorelasi}

Uji autokorelasi berguna dalam menguji terjadinya korelasi pada perbedaan periode waktu yang terjadi di setiap variabel. Penentuan keputusan dalam uji ini menggunakan Durbin-Watson dengan ketentuan $\mathrm{du}<\mathrm{d}<(4-\mathrm{du})$ sebagai penentu tidak terjadinya autokorelasi (Ghozali, 2018).

Tabel 4.5. Uji Autokorelasi

\begin{tabular}{|l|c|r|r|r|r|}
\hline \multicolumn{7}{|c|}{ Model Summary } \\
\hline Model & $\mathrm{R}$ & $\begin{array}{c}\mathrm{R} \\
\text { Square }\end{array}$ & $\begin{array}{c}\text { Adjusted } \\
\text { R Square }\end{array}$ & $\begin{array}{c}\text { Std. Error } \\
\text { of the } \\
\text { Estimate }\end{array}$ & $\begin{array}{c}\text { Durbin- } \\
\text { Watson }\end{array}$ \\
\hline 1 & $.811^{\mathrm{a}}$ & .657 & .612 & .24475 & 2.017 \\
\hline
\end{tabular}

Sumber: Data diolah dengan SPSS 25, 2021

Pada Tabel 5 didapatkan d sebesar 2,017. Dengan sampel sebanyak 70 dan variabel independen berjumlah 8, maka didapatkan du sebesar 1,8735. Jika dibentuk dalam persamaan maka $1,8735<2,017<2,1265$, dan hal ini menunjukkan tidak terjadinya autokorelasi.

\section{Analisis Regresi Linier Berganda}

Tabel 4.6. Hasil Uji Regresi Linier Berganda

\begin{tabular}{|l|r|r|r|r|r|}
\hline \multirow{2}{*}{ Model } & \multicolumn{7}{|c|}{$\begin{array}{c}\text { Unstandardized } \\
\text { Coefficients }\end{array}$} & $\begin{array}{c}\text { Standardized } \\
\text { Coefficients }\end{array}$ & \multicolumn{1}{c|}{$\mathrm{t}$} & \multirow{2}{*}{ Sig. } \\
\cline { 2 - 4 } & \multicolumn{1}{|c|}{$\mathrm{B}$} & Std. Error & \multicolumn{1}{c|}{ Beta } & & \\
\hline (Constant) & -5.413 & 8.063 & & -.671 & .505 \\
\hline CR & -.062 & .057 & -.108 & -1.078 & .286 \\
\hline DER & .374 & .063 & .616 & 5.921 & .000 \\
\hline TATO & -.218 & .082 & -.245 & -2.668 & .010 \\
\hline ROA & .606 & .899 & .070 & .674 & .503 \\
\hline KepMan & -.066 & .012 & -.527 & -5.662 & .000 \\
\hline KepIns & -.250 & .086 & -.235 & -2.903 & .005 \\
\hline Inf & -.084 & .120 & -.066 & -.703 & .485 \\
\hline Kurs & .875 & 1.252 & .066 & .699 & .487 \\
\hline
\end{tabular}

Sumber: Data diolah dengan SPSS 25, 2021

Berikut persamaan regresi yang dibentuk dari hasil uji pada tabel 4.6:

$\mathrm{FD}=-5,413-0,062 \mathrm{CR}+0,374 \mathrm{DER}-0,218 \mathrm{TATO}+$ 0,606ROA - 0,066KepMan 0,250KepIns - 0,084Inf + 0,875Kurs + e

\section{Pengujian Hipotesis}

Uji-t

Pengujian ini dimanfaatkan guna mengetahui pengaruh secara individu (parsial) variabel independen pada variabel dependen. Hipotesis diterima apabila hasil uji-t mempunyai nilai $\mid t$ hitung $\mid>$ dari $t$ tabel dan nilai sig. $<0,05$. Hasil uji t dapat dilihat pada Tabel 4.6 di atas. 


\section{Variabel X1 (Current Ratio)}

Current ratio memiliki nilai thitung $-1.078<\mathrm{t}$ tabel $-2,00030$ dan nilai signifikansi 0,286 $>0,05$. Maka current ratio tidak berpengaruh signifikan terhadap financial distress.

\section{Variabel X2 (Debt to Equity Ratio)}

Debt to Equity Ratio memiliki nilai thitung 5,921> t tabel 2,00030 dan nilai signifikansi $0,000<0,05$. Maka debt to equity ratio berpengaruh signifikan dengan arah positif terhadap financial distress.

\section{Variabel X3 (Total Assets Turnover)}

Total Assets Turnover memiliki nilai t hitung -2,668 > t tabel -2,00030 dan nilai signifikansi $0,010<0,05$. Maka total assets turnover berpengaruh signifikan dengan arah negatif terhadap financial distress.

\section{Variabel X4 (Return on Assets)}

Return on Assets memiliki nilai t hitung 0,674 < t tabel 2,00030 dan nilai signifikansi 0,503 > 0,05. Maka Return on Assets tidak berpengaruh signifikan terhadap financial distress.

\section{Variabel X5 (Kepemilikan Manajerial)}

Kepemilikan Manajerial memiliki nilai t hitung -5,662 > t tabel -2,00030 dan nilai signifikansi $0,000<0,05$. Maka kepemilikan manajerial berpengaruh signifikan dengan arah negatif terhadap financial distress.

\section{Variabel X6 (Kepemilikan Institusional)}

Kepemilikan Institusional memiliki nilai t hitung -2,903 > t tabel -2,00030 dan nilai signifikansi $0,005<0,05$. Maka kepemilikan institusional berpengaruh signifikan dengan arah negatif terhadap financial distress.

\section{Variabel X7 (Inflasi)}

Inflasi memiliki nilai t hitung $-0,703<\mathrm{t}$ tabel $-2,00030$ dan nilai signifikansi 0,485 > 0,05. Maka inflasi tidak berpengaruh signifikan terhadap financial distress.

\section{Variabel X8 (Kurs)}

Kurs memiliki nilai t hitung 0,699 < t tabel 2,00030 dan nilai signifikansi 0,487 > 0,05. Maka kurs tidak berpengaruh signifikan terhadap financial distress.

\section{Uji-F}

Pengujian ini dimanfaatkan guna mengetahui hubungan yang terjadi ssecara bersamaan (simultan) antara variabel independen pada variabel dependen. Hipotesis diterima apabila hasil uji-F nilai $\mid \mathrm{F}$ hitung $\mid>$ dari $\mathrm{F}$ tabel dan nilai sig. $<0,05$.

Tabel 4.7. Hasil Uji-F

\begin{tabular}{|l|r|r|r|c|c|}
\hline \multicolumn{7}{|c|}{ ANOVA $^{\text {a }}$} \\
\hline Model & Sum of Squares & df & Mean Square & F & Sig. \\
\hline Regression & 6.892 & 8 & .861 & 14.381 & $.000^{\mathrm{b}}$ \\
\hline Residual & 3.594 & 60 & .060 & & \\
\hline Total & 10.486 & 68 & & & \\
\hline
\end{tabular}

Sumber: Data diolah dengan SPSS 25, 2021

Dari hasil uji pada Tabel 4.7 di atas, didapatkan F hitung 14,381 > F tabel 2,09, dengan signifikansi $0,000<0,05$. Hal ini mengartikan adanya pengaruh yang tejadi secara bersamaan antara variabel independen terhadap variabel dependen.

Uji Koefisien Determinasi 
Tabel 4.8. Hasil Uji Koefisien Determinasi

\begin{tabular}{|l|r|r|r|r|}
\hline \multicolumn{5}{|c|}{ Model Summary } \\
\hline Model & $\mathrm{R}$ & R Square & Adjusted R Square & $\begin{array}{c}\text { Std. Error of the } \\
\text { Estimate }\end{array}$ \\
\hline 1 & $.811^{\mathrm{a}}$ & .657 & .612 & .24475 \\
\hline
\end{tabular}

Sumber: Data diolah dengan SPSS 25, 2021

Didapatkan hasil koefisien determinasi $\left(\mathrm{R}^{2}\right)$ dari tabel 4.8 sebesar 0,612. Maka dapat dikatakan variabel independen dapat menerangkan pengaruhnya sebesar $61,2 \%$ terhadap variabel dependen.

\section{Pengaruh Current Ratio Terhadap Financial Distress}

Berdasarkan pada hasil uji statistik didapatkan bahwa secara parsial current ratio tidak mempengaruhi probabilitas perusahaan mengalami financial distress secara signifikan. Hal ini terjadi karena sebagian besar perusahaan memiliki nilai currenr ratio dalam posisi aman pada 2015-2019 sehingga perusahaan mampu meminimalisir kemungkinan financial distress. Hasil ini serupa dengan penelitian Aini \& Purwohandoko (2019), Hartianah \& Sulasmiyati (2017), serta Restianti \& Agustina (2018).

\section{Pengaruh Debt to Equity Ratio Terhadap Financial Distress}

Berdasarkan pada hasil uji statistik didapatkan bahwa secara individu DER mampu mempengaruhi probabilitas financial distress secara positif dan signifikan. Ini menerangkan jika semakin tinggi DER yang dimiliki perusahaan, maka probabilitas perusahaan mengalami financial distress akan semakin besar, begitupun sebaliknya. Hasil penelitian ini setara dengan penelitian Diyanto (2020), Masitoh \& Setiadi (2020), dan Hartianah \& Sulasmiyati (2017).

\section{Pengaruh Total Assets Turnover Terhadap Financial Distress}

Berdasarkan pada hasil uji statistik didapatkan bahwa secara parsial TATO mempengaruhi financial distsress secara negatif dan signifikan terhadap financial distress. Dapat dikatakan bahwa rasio TATO perusahaan yang semakin tinggi maka kemungkinan perusahaan mengalami financial distress akan semakin rendah. Hal ini terjadi karena dengan semakin tingginya rasio TATO menggambarkan besarnya efektivitas perusahaan dalam mengelola asetnya untuk mendapatkan pendapatan. Hasil ini sejalan dengan penelitian Adinda \& Musdholifah (2020), Oktarina (2018), dan Kurniasanti \& Musdholifah (2018).

\section{Pengaruh Return on Assets Terhadap Financial Distress}

Berdasarkan uji statistik diperoleh bahwa secara individu ROA tidak signifikan dalam memberi pengaruh pada financial distress. Hal ini mengartikan berapapun nilai ROA yang didapatkan tidak mampu memprediksi terjadinya financial distress pada perusahaan transportasi di tahun 2015-2019. Hasil penelitian ini serupa dengan penelitian Rohmadini et al. (2018) dan Wulandari (2020).

\section{Pengaruh Kepemilikan Manajerial Terhadap Financial Distress}

Berdasarkan pada hasil uji statistik diperoleh secara parsial kepemilikan manajerial memiliki pengaruh terhadap financial distress secara negatif dan signifikan. Hal ini mengartikan jika semakin tinggi kepemilikan manajerial maka akan mengurangi kemungkinan financial distress pada perusahaan. Hal ini terjadi dikarenakan pihak manajerial turut bertanggung jawab atas kepemilikan saham sehingga mengoptimalkan kinerja perusahaan. Hasil penelitian ini serupa dengan Widhiadnyana \& Ratnadi (2019) dan Khursid (2018). 


\section{Pengaruh Kepemilikan Institusional Terhadap Financial Distress}

Berdasarkan pada hasil uji statistik diperoleh bahwa secara parsial kepemilikan institusional memiliki pengaruh terhadap financial distress secara negatif dan signifikan. Ini mengartikan jika semakin tinggi kepemilikan institusional maka mampu meminimalisir probabilitas financial distress pada perusahaan. Hal ini terjadi dikarenakan adanya pengawasan dari pihak institusi lainnya selaku pemegang saham terhadap pihak perusahaan supaya mengoptimalkan kinerjanya. Hasil ini sejalan dengan penelitian Napisah (2020), Li et al. (2020), dan Widhiadnyana \& Ratnadi (2019).

\section{Pengaruh Inflasi Terhadap Financial Distress}

Berdasarkan pada hasil uji statistik didapatkan inflasi secara parsial tidak signifikan mempengaruhi financial distress. Hal ini berlangsung sebab kondisi inflasi yang terjadi pada rentang waktu 2015-2019 dalam kondisi normal dan relatif stabil tiap tahunnya. Hasil penelitian ini selaras dengan Priyatnasari (2019), Napisah (2020), dan Kurniasanti \& Musdholifah (2018).

\section{Pengaruh Kurs Terhadap Financial Distress}

Berdasarkan pada hasil uji statistik didapatkan kurs secara parsial tidak signifikan mempengaruhi financial distress. Ini terjadi karena pergerakan mata uang US Dollar terhadap Rupiah selama kurun waktu 2015-2019 tidak mengalami perubahan yang terlalu tinggi dan relatif stabil. Hasil penelitian ini serupa dengan Setiyawan \& Musdholifah (2020) dan Napisah (2020).

\section{KESIMPULAN}

Berdasarkan hasil penelitian, analisis data, serta interpretasinya, dapat dibuat kesimpulan bahwa secara parsial CR tidak signifikan mempengaruhi financial distress, DER positif signifikan mempengaruhi financial distress, TATO negatif signifikan mempengaruhi financial distress, ROA tidak signifikan mempengaruhi financial distress. Lalu kepemilikan manajerial dan kepemilikan institusional memiliki pengaruh negatif signifikan terhadap financial distress. Serta inflasi dan kurs tidak signifikan mempengaruhi financial distress. Selanjutnya secara simultan seluruh variabel mempengaruhi financial distress dengan tingkat kemampuan menjelaskan sebesar $61,2 \%$. Dengan diketahuinya faktor-faktor yang memiliki peran mempengaruhi financial distress, maka perusahaan diharapkan untuk meningkatkan keahlian perusahaan guna mengciptakan laba dari penggunaan aset yang dimiliki. Hal ini dapat dilakukan dengan mengontrol dan mengurangi beban, memperhatikan investasi dari sumber pinjaman, meningkatkan setiap unit bidang usaha serta memanfaatkan aset secara efektif dan efisien untuk meminimalisir kemungkinan financial distress bahkan kebangkrutan yang mungkin terjadi di masa selanjutnya.

\section{UCAPAN TERIMA KASIH}

Penulis ucapkan terimakasih ke hadirat Allah SWT, atas berkat dan karunaNya sehingga penulis dapat menyelesaikan artikel penelitian ini tepat waktu. Kemudian penulis juga ucapkan terimakasih kepada pihak-pihak yang terlibat yang tidak bisa disebutkan satu per satu.

\section{DAFTAR PUSTAKA}

Adinda, A. R., \& Musdholifah, M. (2020). Pengaruh Rasio Keuangan, Corporate 
Goernance, Dan Makroekonomi Terhadap Financial Distress Pada Perusahaan Yang Terdaftar Di Indonesia Stock Exchange Tahun 2014-2018. Jurnal Ilmu Manajemen, 8, 532-548.

Aini, D. Q., \& Purwohandoko. (2019). Pengaruh Rasio Likuiditas, Leverage, Aktivitas, Profitabilitas dan Sales Growth Terhadap Financial Distress (Studi Kasus pada Perusahaan Sektor Pertambangan yang Terdaftar di Bursa Efek Indonesia Periode 20122016). Jurnal Ilmu Manajemen (JIM), 7(2), 372-381.

BI. (2021). Inflasi. Diambil 15 Februari 2021, dari https://www.bi.go.id/id/moneter/inflasi/pengenalan/Contents/Default.aspx

Diyanto, V. (2020). The Effect of Liquidity, Leverage, and Profitability on Dividend Policy. Indonesian Journal of Economics, Social, and Humanities, 2(2), 127-133. https://doi.org/https://doi.org/10.31258/ijesh.2.2.127-133

Ghozali, I. (2018). Aplikasi Analisi Multivariate Dengan Program IBM SPSS 25. Semarang: Badan Penerbit Universitas Diponegoro.

Hartianah, D. P., \& Sulasmiyati, S. (2017). Pengaruh Aspek Operasional, Corporate Governance, dan Makroekonomi Terhadap Financial Distress (Studi pada Perusahaan Agrikultur yang Terdaftar di Bursa Efek Indonesia tahun 2011-2015). Jurnal Administrasi Bisnis S1 Universitas Brawijaya, 47(2), 65-73.

Hery. (2017). Analisis Laporan Keuangan. Grasindo.

Idarti, \& Hasanah, A. (2018). Analisis Pengaruh Struktur Kepemilikan, Kebijakan Hutang dan Likuiditas Terhadap Financial Distress (Studi Empiris Pada Perusahaan Properti dan Real Estate Yang Terdaftar Di Bursa Efek Indonesia Periode 2013 - 2017). Journal of Applied Managerial Accounting, 2(2), 160-178.

Jenny, S. H. J., \& Wijayanti, R. (2018). Pengaruh Struktur Kepemilikan dan Kinerja Keuangan Terhadap Financial Distress (Studi Pada Perusahaan Manufaktur yang Terdaftar di BEI Periode 2015-2016). Jurnal Ilmiah Mahasiswa FEB, 7(1).

Jensen, M. C., \& Meckling, W. H. (1976). Theory of The Firm: Managerial Behaviour, Agency Costs and Ownership Structure. Journal of Financial Economics, 3(4), 305-360. https://doi.org/10.1016/0304-405X(76)90026-X

Kasmir. (2017). Analisis Laporan Keuangan (8 ed.). Jakarta: RajaGrafindo Persada.

Khurshid, M. K., Sabir, H. M., Tahir, S. H., \& Abrar, M. (2018). Impact of Corporate Governance on the Likelihood of Financial Distress: Evidence from Non-Financial Firms of Pakistan. Pacific Business Review International, 11(4), 17.

Kurniasanti, A., \& Musdholifah. (2018). Pengaruh Corporate Governance, Rasio Keuangan, Ukuran Perusahaan dan Makroekonomi terhadap Financial Distress. Jurnal Ilmu Manajemen, Vol. 6, hal. 197-212. Diambil dari https://jurnalmahasiswa.unesa.ac.id/index.php/jim/article/view/23907 
Li, Z., Crook, J., Andreeva, G., \& Tang, Y. (2020). Predicting the risk of financial distress using corporate governance measures. Pacific Basin Finance Journal, (February). https://doi.org/10.1016/j.pacfin.2020.101334

Mankiw, N. G. (2018). Principles of MacroEconomics, 8th Edition (8 ed.). Boston: Cengage Learning.

Masitoh, S., \& Setiadi, I. (2020). Pengaruh Likuiditas, Profitabilitas, dan Leverage Terhadap Financial Distress (Pada Perusahaan Jasa Sub Sektor Transportasi Yang Terdaftar Di Bursa Efek Indonesia Periode 2014-2017). Competitive Jurnal Akuntansi dan Keuangan.

Matturungan, N. H., Purwanto, B., \& Irwanto, A. K. (2017). Manufacturing Company Bankruptcy Prediction in Indonesia With Altman Z-Score Model. Jurnal of Applied Management (JAM), 15(1), 18-24. https://doi.org/10.18202/jam23026332.15.1.03

Mintzberg, H. (1983). Power in and Around Organizations (The theory of management policy). Prentice Hall. Diambil dari http://www.amazon.com/Around-Organizationstheory-management-policy/dp/0136868576

Napisah, L. S. (2020). The Effect of Good Corporate Governance and Macroeconomics Factors Towards Financial Distress. Review of Behavioral Aspect in Organizations and Society, 2(1), 39-50. https://doi.org/10.32770/rbaos.vol239-50

Oktarina, D. (2018). Prediksi Financial Distress Menggunakan Rasio Keuangan, Sensitivitas Makroekonomi dan Intellectual Capital. ULTIMA Accounting, 10(1), 16-33.

Platt, H. D., \& Platt, M. B. (2002). Predicting Corporate Financial Distress: Reflections On Choice-Based Sample Bias. Journal of Economics and Finance, 26(2), 184-199. https://doi.org/Https://Doi.Org/10.1007/Bf02755985

Priyatnasari, S., \& Hartono, U. (2019). Rasio Keuangan, Makroekonomi Dan Financial Distress: Studi Pada Perusahaan Perdagangan, Jasa Dan Investasi di Indonesia. Jurnal Ilmu Manajemen, 7, 1-12.

Rahardja, P., \& Manurung, M. (2017). Pengantar Ilmu Ekonomi (Mikroekonomi \& Makroekonomi) (3 ed.). Jakarta: Fakultas Ekonomi Universitas Indonesia.

Restianti, T., \& Agustina, L. (2018). The Effect of Financial Ratios on Financial Distress Conditions in Sub Industrial Sector Company. Accounting nalysis Journal, 7(1), 25-33. https://doi.org/10.15294/aaj.v5i3.18996

Rohmadini, A., Saifi, M., \& Darmawan, A. (2018). Pengaruh Profitabilitas, Likuiditas dan Leverage Terhadap Financial Distress (Studi Pada Perusahaan Food \& Beverage Yang Terdaftar Di Bursa Efek Indonesia Periode 2013-2016). Jurnal Administrasi Bisnis, 61(2), 11-19. 
Setiyawan, E., \& Musdholifah. (2020). Pengaruh Struktur Kepemilikan, Profitabilitas, Likuiditas, Leverage, dan Nilai Tukar Terhadap Financial Distress pada Perusahaan yang Terdaftar di IDX Tahun 2016-2017. Jurnal Ilmu Manajemen (JIM), 8(1), 51-66.

Sudana, I. M. (2019). Manajemen Keuangan Perusahaan: Teori dan Praktik (2 ed.). Jakarta: Erlangga.

Widhiadnyana, I. K., \& Ratnadi, N. M. D. (2019). The impact of managerial ownership, institutional ownership, proportion of independent commissioner, and intellectual capital on financial distress. Journal of Economics, Business \& Accountancy Ventura, 21(3), 351. https://doi.org/10.14414/jebav.v21i3.1233

Wulandari, S. (2020). Pengaruh Rasio Keuangan Dalam Memprediksi Financial Distress Pada Sektor Pertanian Yang Terdaftar Di Bursa Efek Indonesia. Prosiding Seminar Nasional Hasil Penelitian dan Pengabdian kepada Masyarakat Unjani Expo, 1(1), 87-90. Diambil dari http://journal.unjani.ac.id/index.php/unex 